\title{
Et delt mediemarked: Prosesser som fremmer små aviser
}

\section{AF ASTRID MARIE HOLAND}

Nord-Norge, Europas nordlige utkant, er en region kjennetegnet ved store avstander og spredt befolkning. Her ser det ut til at flere forhold sammen fremmer et desentralisert og superlokalt mediemarked. Økonomiske, politiske, teknologiske og sosiale faktorer peker i samme retning: Isteden for avisdød, ser vi mange nye småaviser. Spørsmålet blir da om denne «grasrotprosessen» er et svar på utfordringer bransjen som helhet møter. Kan det tenkes at dette skjer fordi sentralisering, konsernoppkjøp og digitalisering pågår? Det er tema for artikkelen, basert på en studie av utviklingen hos de førti avisene som utgjorde den trykte lokalpressen i Nord-Norge i årene 1990-2010.

\section{Innledning}

I en rapport fra Annenberg School for Communication and Journalism blir papiravisas død nok en gang forutsagt, denne gangen omkring 2017, dog med visse viktige unntak - de aller største og de aller minste:

[T]he only print newspapers that will survive will be at the extremes of the medium - the largest and the smallest.[...] local weekly and twice-weekly newspapers may continue in print form

USC Annenberg School Center for the Digital Future, 2012:13

Imidlertid kan det være helt ulike grunner til at disse to avistypene ser ut til å klare seg. Da Philip Meyer gjorde opp status for makrotrender i pressebransjen, mente han at store og små 
avismarkeder er kvalitativt forskjellige i den grad at store og små aviser følger ulike spilleregler. Han etterlyste også mer forskning på området: «If the rules are different, somebody needs to discover and codify them» (Meyer, 2004:27-30). Denne undersøkelsen av utviklingen i et utvalg lokale papiraviser gjennom 20 år kan være et bidrag i så måte. Selv om alle disse avisene er «små» i Meyers målestokk, er det vesentlig forskjell i størrelsen på aviseierne, slik at både den «store» og den «lille» markedslogikken kommer til syne.

Dette er på den ene siden en historie om konsentrasjon og sentralisering. På den andre siden er det historien om nisjer som blir ledige - og som kan inntas med de ressursene lokale initiativtakere har til rådighet. Dynamikken i forholdet stor - liten er altså av interesse her.

Formålet med artikkelen er å gi oversikt over utviklingen i et lokalt mediemarked, i møte med grunnleggende endringer som har pågått i bransjen, også internasjonalt. Slik kan vi si noe om hva som har ledet til dagens situasjon i et gitt område. For å få dette til er en hel kategori mediebedrifter, de betalte papiravisene, fulgt fra 1990 til 2010. ${ }^{1}$ Geografisk er undersøkelsen avgrenset til Norges tre nordligste fylker, Nordland, Troms og Finnmark, et område som i flere henseender betraktes som ett mediemarked. Det gjelder politisk (Forskrift om medieregioner, 2005-0701 nr. 754) og forretningsmessig. På annonsemarkedet selges såkalte «Nord-Norge-pakker» - av klimatiske grunner. Her oppe i det kalde nord er det fortsatt for tidlig å reklamere med lave sko og sommerklær i mars måned. Regionen har også sine egne geografiske utfordringer, som jeg kommer tilbake til.

La meg først gi et eksempel på hvordan store aktører i bransjen opptrer. I 2001-02 var jeg vitne til en spesiell hendelse i presselandskapet i min hjemby Bodø i Nord-Norge: To lokale dagsaviser, politiske motstandere, arge konkurrenter i 90 år - og som tilhørte konkurrerende konsern - ble slått sammen. En viktig årsak til at den tidligere høyreavisa og den tidligere arbeiderpartiavisa ble slått sammen, var at konserneierne ville ha slutt på en ødeleggende priskonkurranse på annonser. De to avisene hadde i lang tid underbydd hverandre, og konserneierne fryktet at de altfor lave annonseprisene i Bodø skulle forplante seg til resten av landsdelen via kunder som også hang sammen i kjeder (Bodø- 
gaard, 2012: 213-221). Slik gikk det til at to ellers konkurrerende konsern gikk sammen om å starte én ny dagsavis i Bodø.

De to konsernene som sto bak sammenslåingen, er fortsatt de dominerende aviseierne i regionen: Amedia (tidligere A-pressen) og Polaris Media (der den tidligere Harstad Tidende Gruppen inngår). Dem får vi høre mer om. Nord-Norge var utvilsomt en relevant størrelse å ta hensyn til da to aviser i Bodø ble omgjort til én. Her var hensynet til det felles nordnorske annonsemarkedet avgjørende. «Det var økonomiske krefter som drev fusjonen fram», skrev medieforsker Ivar Andenæs om avissammenslåingen, og han fortsetter: «De økonomiske lover krever større enheter. [...] Avisoppkjøp er i stigende grad blitt et middel for konsernene til å fylle huller $i$ sine annonsesamkjøringer» (Andenæs, 2003: 13-14).

Andenæs uttrykte en utbredt tanke i tiden. På 1990- og 2000-tallet ble avisoppkjøp i stigende grad betraktet som en løsning på problemer konsernene møtte. Veksten i de tre største aviseiernes andeler av totalopplaget i Norge, viser hvor rask eierkonsentrasjonen var: Schibsteds, A-pressens og Orklas (senere Eddas) samlede eierandel av norsk dagspresse økte fra 51 til 61 prosent på ti år (1988-98). Til sammen eide de, helt eller delvis, 45 aviser i 1990, 71 aviser i 1998 og 105 aviser i 1999 (Bakke, 2000: 190). Disse tre var fortsatt dominerende i 2010. Da kontrollerte de sammen med Polaris-gruppen, som er en relativt stor aktør i Midt- og Nord-Norge, 67 prosent av det totale avisopplaget (Skogerbø, 2012:12). Siden har A-pressen kjøpt Edda, og opptrer nå under navnet Amedia, men det faller utenfor artikkelens fokus.

At de økonomiske lover krever større enheter, er imidlertid en sannhet med modifikasjoner. Et av de interessante trekkene som kommer fram i denne undersøkelsen, er at det nordnorske medielandskapet har god tilvekst av nye små selvstendige bedrifter som gir ut betalte papiraviser. Slik har det vært andre steder i Norge også, men hvis vi ser på det siste årets utvikling, virker det som at markedet for superlokale aviser begynner å mettes ellers i landet. I 2012 ble 4 av 4 nye norske aviser i denne kategorien startet i Nord-Norge, og fra årsskiftet 2013 kom enda en (Høst, 2013: 14, 17, 64-70). Spørsmålet blir da rett og slett om dette - som jeg kaller grasrotprosessen - er et slags svar på de utfordringene bransjen $i$ regionen som helhet møter. For å finne ut av det, må 
vi undersøke hvilke utfordringer lokalpressen her i utkanten av Europa har møtt, og hvordan den har møtt disse utfordringene.

Denne studien av førti lokalavisers utvikling gjennom tjue år er i stor grad basert på dokumentanalyse. En hovedkilde er lokalavisenes årsregnskap og årlige styreberetninger, supplert med oversiktsstatistikk og enkelte informantintervjuer. ${ }^{2}$ Årsberetningen har sine svakheter som kilde, men for å hente ut nøkkeltall og makrotrender, er dette likevel et godt datamateriale. ${ }^{3}$ Jeg vil bruke noen enkeltaviser som eksempler for å trekke opp utviklingslinjer for konkurransesituasjonen, eierskap, teknologi og organisering. Disse hovedlinjene belyses ved hjelp av Porters modell for bransjeanalyse (Porter, 2008, se fig. 1 og 2). Endringer i norsk mediepolitikk må også tas i betraktning, som én faktor som kan fremme et desentralisert og superlokalt mediemarked.

\section{Oversikt over et mediemarked}

Nordmenn regnes som et avislesende folk, med det høyeste antall betalte aviser i Norden (226 i 2010). Nordicoms statistikk viser at Norge sammen med Finland ligger på topp hva angår opplaget for betalte aviser per 1000 innbyggere (Nordicom, 2013). Papiravisopplaget i Norge har imidlertid vært fallende i en årrekke. Samlet sett var det på sitt høyeste i 1994. Det var før nettavisenes vekst begynte. Etter 1994 har særlig de gamle og store papiravisene, på alle geografiske nivåer, hatt opplagsfall - mens flere nye og små klarer seg bra. (Medieåret 2008-2009:10, Høst, 2011:6-7). I Norge er superlokale ukes- og fådagsaviser i hovedsak betalte aviser - i motsetning til i Danmark, der et stort antall slike aviser er gratis.

Datamaterialet mitt følger en gruppe lokalaviser gjennom høyog lavkonjunkturperioder, fra den optimistiske «jappetida» sist på 1980-tallet, der 1987 var topp-året for annonsesalg. Deretter opplevde Norge en omfattende gjeldskrise. Det er én forklaring på at mange lokalaviser var i en presset økonomisk situasjon ved inngangen til 1990-tallet, som er denne undersøkelsens startpunkt. Utover 2000-tallet opplevede avisene ny vekst, med 2007 som toppåret, fram til den internasjonale finanskrisen slo inn i 2008/2009 - med påfølgende sparetiltak. I perioden vi ser på her 
ble avisene utfordret på både annonse- og lesermarkedet, særlig fordi digitaliseringen i media banet vei for en rekke nye konkurrenter. Når så avisene opplevde at hovedinntektskildene deres var truet, var det klart at de måtte foreta seg noe.

At avisene i undersøkelsen har hatt store økonomiske utfordringer, fremgår av deres årsresultater og utvikling i driftsmargin (driftsresultat som prosentandel av driftsinntekt før skatt). Det er en klar samvariasjon mellom deres resultater og konjunktursvingninger i samfunnet for øvrig. På annonsesiden er avisene et følsomt barometer for situasjonen i lokalt næringsliv. Fokuset på egen (mangel på) bedriftsøkonomisk lønnsomhet har økt. Eierkonsentrasjonen er også en sentral del av historien. Når det økonomiske fundamentet trues, er oppkjøp en opplagt vei å gå - for de store aktørene, vel å merke - for å skaffe seg markedsandeler og stordriftsfordeler. Neste skritt blir samarbeid og funksjonsdeling innenfor konsernene, med trykking, tekniske løsninger, stoffutveksling - og de organisatoriske konsekvensene som følger. De samme hovedtrendene for eierkonsentrasjon, organisering og konkurranseforhold har Høst (2012) og Krumsvik (2012) beskrevet på landsbasis.

\section{Lokale særtrekk som fremmer små aviser}

Det geografiske området Nord-Norge utgjør 112976 km², inkludert mange små og store øyer langs den lange, kronglete kysten (Kartverket 2013).Ved inngangen til 2012 bodde 471000 mennesker her, etter et år med en rekordartet tilvekst på 0,5 prosent (Statistisk Sentralbyrå 2013). Folk bor spredt, det er snakk om store distribusjonsavstander, og ofte mangelfull infrastruktur utenfor byene. Dette har alltid gitt nordnorske avisbedrifter ekstra utfordringer. Med strammere økonomi, ble slike utfordringer opplevd som mer problematiske enn før. Flere årsberetninger nevner at reduksjoner i postverkets tjenester er et tilleggsproblem. Dessuten førte fraflytting fra distriktene til at en del lokalaviser bekymret seg for svikt i publikumsgrunnlaget. Byene Tromsø, Bodø og Alta har hatt sterk befolkningsvekst i mange år, men over halvparten av nordnorske tettsteder opplevde at folketallet stagnerte eller gikk tilbake i årene 2000-2009. Enkelte steder mistet også 
status som tettsted, det vil si at de fikk mindre enn 200 innbyggere (Aarsæther og Nyseth, 2011: 58). I denne undersøkelsens materiale er det en klar tendens til at når opplaget falt, forklarte avisstyrene det med omkringliggende omstendigheter, som lavkonjunktur eller generelle trender i bransjen, men også fraflytting. En kommune som opplevde fraflytting gjennom 1990-tallet var Andøy:

Fremtidsutsiktene for Andøy er til dels urovekkende med fare for ytterligere befolkningsnedgang og negativ utvikling i det lokale næringsliv.

Andøyposten, årsberetning for 1994

Flere av de etablerte lokalavisene gjengir egne leserkartlegginger som viser at lesertallene svekkes i utkanten av nedslagsfeltet. Det må sees i sammenheng med to generelle tendenser. Det foregår en tettstedsfortetting, der folk flytter fra periferi til lokale sentra (Aalbu 2004, Barlindhaug 2004, Statistisk Sentralbyrå 2012). For avisene bidrar dyrere og dårligere distribusjon dessuten til et relativt større frafall av abonnenter i periferien, men disse kundene er samtidig de minst lønnsomme for avisa (Okkenhaug 2011).

Blant de etablerte avishusene i lokalpressen skaper dette en trend som går tydelig frem av materialet i undersøkelsen, og den trenden kan kalles lokalsentralisering. Når økonomien oppleves som presset, er det ikke regningssvarende å dekke et for stort geografisk område, og særlig ikke her hvor vi snakker om store lokalregioner målt i areal. Mange av de eldre bedriftene har også vært gjennom ressurskrevende omstillinger i teknologi og organisering. Alt dette bidrar til at de gjør sparetiltak, som i neste omgang reder grunnen for nye utfordrere. Når etablerte aviser konsentrerer seg om å ta vare på de mest trofaste leserne og annonsørene i kjerneområdet, der distribusjonen er mest stabil, blir bemanningen ved lokalkontorer redusert eller kuttet helt ut. Da åpner det seg et marked for en ny avis der den gamle har trappet ned. La oss ta et eksempel fra Vardø i Finnmark. Her la den konserneide dagsavisa Finnmarken ned lokalkontoret sitt i 1994 - og her ble den nye superlokale avisa Østhavet etablert i 
1997. Finnmarken dekker fortsatt flere kommuner, mens Østhavet bare dekker én.

Superlokale aviser er i utgangspunktet lokalorienterte. Karakteristisk for dem er nettopp at de dukker opp på steder utenfor kjerneområdet for større, etablerte lokalaviser som dekker mer enn en kommune. Man kan altså se for seg at det rundt omkring finnes publikum som synes at deres eget lokalmiljø får for liten pressedekning. Nye aviser som retter seg spesielt mot slike lokalmiljøer kan oppnå status som et reelt supplement til eksisterende medietilbud, og slik kapre en del av markedet. Okkenhaug (2011:79) viser også at nisjeaviser relativt sett har mer betalingsvillige lesere. Det superlokale mediemarkedet fremstår som en arena for lokal stolthet og identitet, men også for debatt om lokale saker som ikke hadde kommet over nyhetsterskelen i de større distrikts- eller regionavisene. Her kommer vi inn på en funksjon ved lokalaviser som kan oppleves som et mottiltak mot fraflytting og pessimisme, ja, endog mot de generelle sentraliseringstendensene i pressen. Østhavet, som i oppstartsåret ble kåret til «årets lokalavis», hadde som erklært mål å «arbeide for å fremme en positiv utvikling i lokalsamfunnet og stimulere til samfunnsdebatt»(årsberetning for 1997). Sør-Varanger Avis i nabobyen Kirkenes, som er medeier i Østhavet, supplerte i sin årsberetning for 1998: «En lokalavis skal voere talerør for alt som skjer i lokalsamfunnet. Det forutsetter godt og tillitsfullt forhold mellom avisens ansatte og befolkningen.» En lokalavis kan ta i bruk kultur- og/eller distriktspolitiske verktøy ved å etablere seg som lokaloffentlighetens forsvarer. Dette ser ut til å være en svært viktig drivkraft i grasrotprosessen. Slik kan de vinne goodwill fra lokalt næringsliv og lokale lesere, og dessuten få pressestøtte. Superlokale fådagsaviser er en av målgruppene for den offentlige pressestøtten i Norge (Roppen 2012).

Selv om denne artikkelen handler mest om hva pressen foretar seg, er det også nødvendig å se litt på hva myndighetene har foretatt seg. Da pressestøtten ikke greide å opprettholde direkte konkurranse mellom lokalaviser med ulike partipolitiske syn, ble subsidiepolitikken lagt om, for å sikre mangfold og konkurranse i bransjen på andre måter. Å bidra til at det kan utkomme aviser flest mulig steder hvor det er grunnlag for det, var ett slikt tiltak (Larsen, 1992: 12). Slik har pressestøtten bidratt til å holde liv i en 
flora av lokale fådagsaviser og meningsbærende aviser (Bakke, 2000: 180-181). Finanskrisen i 2008/09 har ikke gitt noe tilbakeslag som ligner på det avisene opplevde rundt 1990. I stedet kan det se ut til at den langsiktige veksten i antall aviser på landsbasis er avløst av stagnasjon (Høst, 2013:17).

I Nord-Norge er det fortsatt avisvekst. Det samlede antallet nordnorske avishus har gått litt opp og ned i løpet av tjue år; eldre har forsvunnet, mens nye har kommet til. Langtidstrenden er likevel at det ble flere aviser: 28 i 1990, 33 i 2000, 34 i 2010. I 2012 fantes 37 betalte lokalaviser her, når vi tar med dem som var i etableringsfasen. Det er klart at pressestøtten har vært avgjørende for eksistensen til mange lokalaviser, og for at noen i det hele tatt våger seg på å starte avis. Blant direkte støttetiltak finnes egne tilskudd til samiske aviser og distribusjonstilskudd til aviser i Finnmark (Slettholm, 2010: 34). Det er likevel ikke sikkert at det er hele forklaringen.

\section{To motsatte prosesser gir et todelt marked}

Denne oppsummeringen har så langt hovedsakelig belyst hvilke utfordringer pressen har møtt. Noen mottrekk er nevnt, som endringer i nedslagsfelt og organisering. La oss nå se hvordan strukturendringer i bransjen kan ha hatt betydning for etableringen av nye småaviser.

Tradisjonelt var de nordnorske lokalavisene enten familiebedrifter, med et lite antall private eiere, eller andelslag med enkelte store og mange små lokale aksjonærer. De større eierne i andelslagene var typisk en kommune, et parti eller en forening. I samiske aviser har samiske interesseorganisasjoner vært betydelige eiere. I arbeideravisene hadde mange lokallag og fagforeninger noen få aksjer hver, mens fylkespartiet hadde en større aksjepost. Altså hadde lokalpressen her i utgangspunktet en tydelig forankring i lokal identitet. De siste tjue årene er mange slike tradisjonelle lokale eiere kjøpt ut og erstattet av industrielle konserneiere, men det fins unntak. Ett unntak er Svalbardposten i Longyearbyen: Den har én aksje, som eies av en privat næringsdrivende stiftelse. Det finnes også eksempler på at konsernoppkjøp har blitt stanset av avisenes styrer, eller ved at lokale 
aksjonærer har aksjonert. Noen ganger har det blitt rettstvister av at et avisstyre nektet å godkjenne et aksjesalg. Flere aviser har nemlig hatt vedtekter som var ment å skulle motvirke eierkonsentrasjon. Andre ganger har lokale eiere mobilisert motkapital for å stoppe planlagte aksjekjøp fra konsernenes side. Selv om slike eksempler forteller noe om lokal motstand mot det jeg her kaller konsernifiseringsprosessen, hører slike historier likevel til unntakene. La oss se litt nærmere på hovedtrekk i hvordan eierskap i nordnorske aviser har utviklet seg.

Mange av lokalavisene i denne undersøkelsen ble etablert i partipressens dager. Mens arbeideravisene ble etablert som andelslag, var borgerlige aviser ofte familiebedrifter. I 1990 eksisterte fortsatt en håndfull slike familiebedrifter, alle med lange tradisjoner i bransjen. For dem fantes tre mulige utviklingsruter; å gjøre det som krevdes av oppgradering for å forbli selvstendig, bli videreført i konsern, eller bli lagt ned. Ofte ble de med svakest $ø$ øonomi kjøpt opp. Da kunne konserntilknytning fremstå som redningen - et bedre alternativ enn konkurs.

Utover 1990-tallet kjøpte avisene ofte aksjer i hverandre. Det bar preg av konsolidering gjennom krysseierskap og/eller oppkjøp i retning av å skaffe seg majoritet. Selv om politisk forankret eierskap i pressen regnes som tilbakelagt stadium, fremsto eierkonsentrasjonen i denne regionen først som del av konkurransen mellom Norsk Arbeiderpresse (nå Amedia) og de tidligere borgerlige avisene med Harstad Tidende i spissen. Norsk Arbeiderpresse ble omdannet til konsern i 1990, etter hvert under navnet A-pressen. Målet for konserndannelsen var å bli mer slagkraftig og konkurransedyktig, etter en tid med synkende markedsandeler på landsbasis (Bodøgaard, 2012: 208, Finnmark Dagblads og Helgeland Arbeiderblads årsberetninger for 1990). På det tidspunktet hadde konsernet eierinteresser i sju tradisjonelle nordnorske arbeideraviser. På den andre siden finner vi Harstad Tidende, som opptrer som konsern fra 1992, fra 1999 under navnet Harstad Tidende Gruppen (HTG, i dag en del av Polaris-konsernet). I disse årene ble flere aviser, samt enkelte lokale radio- og TV-stasjoner, tilknyttet eller fullstendig innlemmet i det ene eller andre av disse konsernene. Mange lokale mediebedrifter hadde behov for å styrke egenkapitalen, derfor var styrene som oftest positive til at andre aviser kjøpte aksje- 
poster. En fremgangsmåte var å foreta kapitalutvidelser gjennom rettede emisjoner. Det foregikk ofte i tråd med tradisjonelle partiskillelinjer: Arbeideraviser rettet seg mot A-pressen, borgerlige aviser rettet seg mot hverandre. Det fantes en klar oppfatning av at det var viktig å knytte økonomiske allianser:

Med den utvikling som skjer i bransjen, mot større enheter og kjededannelser, blir samarbeidet mellom uavhengige aviser $i$ landsdelen stadig viktigere. [...] Med det samarbeid som utvikles, blir også avisene mer avhengig av hverandre. Felles IT-systemer og strategier utvikles, og ved endringer i eierskap må man i større grad enn tidligere sikre nettverkene ved krysseierskap.

Harstad Tidende, årsberetning for 1995

Når mange markedsaktører opplever at utviklingen går denne veien, og de innretter sine handlinger deretter, blir prosessen selvforsterkende. Etter noen år med denne utviklingen er krysseierskap mellom avisbedrifter blitt vanlig, noe som gjør eierstrukturene uoversiktlige på detaljplan. Morkonsernene har fått både «niese-», datter- og datterdatterselskaper.

Fra 1990 til 2000 ble flere lokalaviser konsernavhengige. I Nord-Norge gikk andelen frittstående aviser ned fra 64 til 30 prosent på disse ti årene. Mens eierkonsentrasjonen pågikk, ble det spurt om de nye eierstrukturene styrket eller svekket pressens uavhengighet, og hva eierskap hadde å si for ytringsfriheten. Et eksempel er eierskapsutvalgets utredning fra 1995 (Skarstein 1995). Utvalgets hovedoppgave var å vurdere om eierkonsentrasjon og krysseierskap begrenser ytringsfriheten. Konklusjonen var at uavhengighet i forhold til staten oppfattes som det viktigste kriteriet for frie medier. Markedsmedier ble oppfattet slik at de i seg selv leder til konkurranse. Økonomisk sterke mediebedrifter ble oppfattet som mer standhaftige mot press av ulik art. Det ble også påpekt at nasjonale og regionale medier bare kunne forsvare seg mot multinasjonale oppkjøp gjennom konsentrasjon og konsolidering.

Beretninger fra aviser i begge «blokkene» viser at konkurransen i det nordnorske avismarkedet opplevdes som skjerpet under konsernifiseringsprosessen. Snart ble det også handlet på tvers av gamle partiskillelinjer, som da A-pressen kjøpte to 
tidligere borgerlige aviser, i 1995 og 1998. «A-pressen er blitt en aggressiv oppkjøper», het det i Harstad Tidendes årsberetning for 1998. Om seg selv skrev styret i Harstad Tidende at «selskapet gikk inn i 2000-tallet som et nordnorsk mediekonsern i ferd med å posisjonere seg for et nytt årtusen» (Harstad Tidende, årsberetning for 1999). Fra 2000 opptrer Harstad Tidende Gruppen som reorganisert konsern. I 2008 var de med å starte det nye konsernet Polaris Media.

Ved siden av denne konsernifiseringsprosessen, har samtidig det vi kan kalle en grasrotprosess funnet sted. Mens etablerte mediebedrifter ble samlet i voksende konsern, spirte nye uavhengige småbedrifter opp. Dagens nordnorske mediemarked er dermed todelt; det preges av to store og mange små aktører. De to store er Amedia og Polaris Media, som er eiere i et flertall av lokalavisene her. Etter tusenårsskiftet, har andelen konsern-uavhengige lokalaviser likevel økt, fra 30 prosent i 2000 til 38 prosent i 2010. Blant de uavhengige finnes fortsatt noen gamle familiebedrifter, og noen eldre fådagsaviser, men flertallet av de frittstående er superlokale aviser som startet etter 1990.

\section{Reell forankring har betydning}

De nye superlokale avisene blir vanligvis startet som lokale spleiselag, der en gründer, lokalt næringsliv og eventuelt et kommunalt næringsutviklingsselskap går inn som aksjonærer. Disse avisene kommer ut 1-2 ganger i uka, og dekker som oftest bare en kommune. I 2013 fantes det 11 slike aviser i Nord-Norge, men tallet endrer seg hele tiden. ${ }^{4}$ Dette oppfattes fortsatt som en mulighetenes nisje, selv om ikke alle som forsøker seg lykkes. De som gir opp, begrunner det ofte med at det lokale markedsgrunnlaget er for dårlig. Dersom markedssegmentet er for lite, er det ikke nok at de få leserne som fins der er betalingsvillige.

Jeg skrev med vilje at superlokale aviser vanligvis startes som spleiselag, for det finnes også andre eksempler. Det har kommet til nye lokalaviser som ikke hører til denne såkalte grasrotprosessen, men som heller er «top-down-initiativer». Både A-pressen og Harstad Tidende Gruppen har forsøkt å etablere nye småaviser i motstanderens «revir», som et ledd i konkurransen 
mot hverandre (Bodøgaard, 2012:209). Disse avisene fant dårlig fotfeste i lokalmarkedet, og ble for kortvarige til å komme med i denne undersøkelsens hovedmateriale.

I Nord-Norge finnes dessuten to nyere dagsaviser som eies av Amedia og Polaris i samarbeid. Disse to avisene er spesielle på en annen måte også: De er to av de i alt tre nye dagsavisene som er etablert i Norge etter 2000, der samtlige var resultat av sammenslåing mellom eldre aviser. Den ene er Avisa Nordland i Bodø, som ble omtalt innledningsvis, der Amedia er majoritetseier. Den andre er den samiske avisa Ávvir i Karasjok, der de to konsernene har like store andeler. Ávvir ble etablert på den samiske nasjonaldagen, 6. februar, i 2008. Den var resultatet av at to samisk-språklige aviser, en fra hvert konsern, ble slått sammen. I 2008 ble nok en nordnorsk avis gjenstand for sammenslåing: Bransjeorienterte Fiskeribladet, eid av Norges Råfisklag, ble overtatt av Bergens-baserte Fiskaren, og de to avisene ble slått sammen til én fådagsavis med fiskeri- og havbruksnæringen som målgruppe.

Det er verd å merke seg at samtlige av de gamle avisenes styrer uttrykte stor fremtidsoptimisme på de nye avisenes vegne i siste årsmelding før sammenslåing. Markedet reagerte ikke med samme entusiasme. Både FiskeribladetFiskaren, Avisa Nordland og Ávvir har hatt opplagsfall, og topper bare så vidt det opplaget de respektive gamle avisene før sammenslåingen hadde hver for seg. I Bodø ble det gjort flere «grasrot-forsøk» på å utfordre Avisa Nordland (Holand, 2012:236), og FiskeribladetFiskaren har fått en ny nordnorsk utfordrer i nyetablerte Kyst og Fjord, som også retter seg mot lesere i fiskerinæringen.

Det er altså ikke gitt for en hvilken som helst aktør å lykkes med en lokalavisetablering. Dette later heller ikke til å være utelukkende et spørsmål om økonomiske ressurser, for konsernene har sånn sett stått bedre rustet enn lokale initiativtakere. Til sammen kan dette tyde på at grasrotprosessen - at nye små aviser startes på lokalt initiativ - også kan oppfattes som en reaksjon mot konsernifiseringsprosessen, som ofte har vært styrt av aktører utenfor lokalsamfunnet. Reell lokal forankring - i form av tradisjoner knyttet til stedet, eller sosiale nettverk knyttet til stedet har betydning for at det lokale markedet skal få et eierforhold til avisa. En casestudie av en relativt nystartet lokalavis i Nordland, Framtia som ble etablert i 2008, viser dessuten at lokale allianser 
var avgjørende for å minske risiko knyttet til selve etableringsfasen, der det gjaldt å skaffe aksjonærer, annonsører, abonnenter og ambassadører for det nye produktet (Hansen, Holand og Morlandstø, utkommer 2014).

Meyer fant i sin undersøkelse at nordamerikanske papiraviser som var forankret i lokalsamfunn hadde større robusthet mot opplagsfall, og knyttet dette til at de nøt en særlig tillit hos sine lesere (Meyer, 2004:22-30). La oss nå kaste et blikk på de eldre, etablerte lokalavisene i min undersøkelse, og se på hva størrelsen driftsmargin i kombinasjon med opplag kan fortelle om deres robusthet. Dagsavisene har hatt fallende opplag, og det er særlig de største av dem som rammes. For en del slo dette imidlertid inn senere enn i 1994. Til sammenlikning har både nyetablerte og eldre ultralokale fådagsaviser opplevd perioder med opplagsvekst. Jevnt over, har dagsavisene likevel en bedre driftsmargin enn fådagsavisene. Rana Blad, en middelsstor dagsavis i Amedia-konsernet, er den som peker seg ut. Blant nordnorske dagsaviser med opplag over 10000 har Rana Blad den mest stabile utviklingen i opplag og inntjening sett under ett, gjennom 20 år. Her er det interessant å merke seg at dette er en av relativt få aviser som gjennomgående beskriver det lokale annonsemarkedet som stabilt. Stødig lokalt fundament ser altså ut til å gi stamina.

\section{Markedsanalyse}

Utvalget som vurderte norsk mediepolitikk i 1995, ga en god prognose for de kommende år:

Teknologien åpner for helt nye medietyper. De elektroniske mediene er i ferd med å ta et nytt sprang. En ny konsumentutviklet medieteknologi vil være utviklet $i$ løpet av den kommende tiårs periode, og den vil stille helt nye økonomiske og politiske utfordringer.

Skarstein 1995: pkt. 7

La oss ta veien om Porters (2008, fig. 1) bransjeanalyse mens vi ser nærmere på utviklingen i konkurransesituasjonen. Denne analysen kan brukes til å kartlegge eksterne faktorer som påvir- 
Figur 1. De fem kreftene i industrikonkurranse (Porter, 2008)

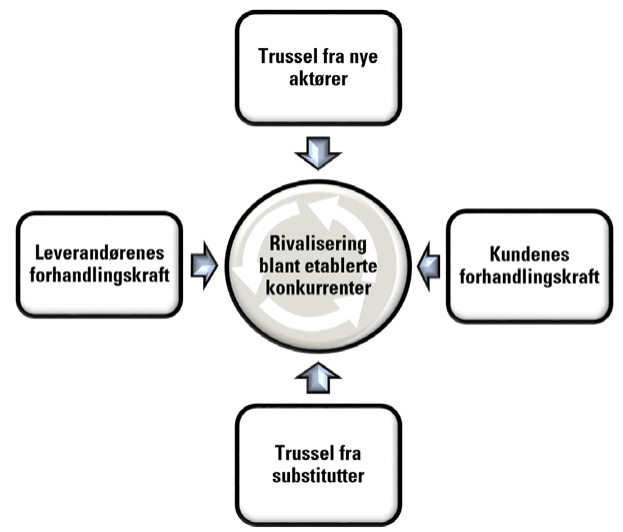

ker en bedrifts konkurranseevne og dynamikken i industrien bedriften opererer $\mathrm{i}$.

Hovedelementene i Porters modell er: 1) direkte konkurrenter, 2) leverandørenes forhandlingskraft, 3) kundenes forhandlingskraft, 4) potensielle nye aktører i bransjen og 5) substitutter, det vil si produkter fra andre bransjer som kan dekke tilsvarende behov. Som Krumsvik (2012) påpeker, er nyhetsmarkedet så sammensatt at de ulike delene av det må analyseres på egne premisser. Dersom vi anvender Porters analyse av markedskrefter, sett fra de etablerte lokalavisenes ståsted, får vi situasjonen som er illustrert i fig. 2

Figur 2. Utfordringer i lokalavismarkedet, illustrert med Porters modell (2008)

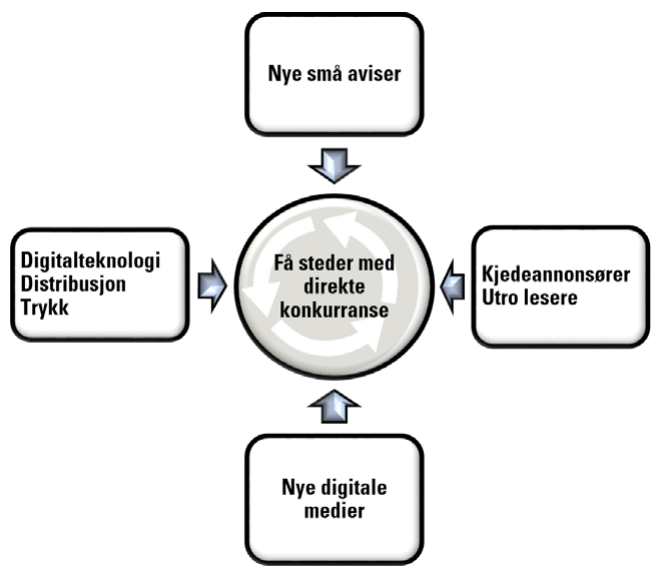


Direkte konkurranse oppleves i liten grad, noen lokalaviser kan likevel ha overlappende målgrupper/nedslagsfelt. Det skyldes ikke minst de nye superlokale avisene. Leverandørenes forhandlingskraft er større overfor små aviser som kjøper design-, IT-tjenester, trykk og distribusjon sammenliknet med pressekonsern som selv sørger for slike tjenester. Konkurransesituasjonen er ellers endret fra å være dominert av direkte konkurranse mellom ulike partiaviser, til å bli mer og mer preget av konkurranse mot substitutter; kringkasting, nettaviser og sosiale medier. De store aktørene har svart på utfordringen fra de digitale substituttene ved å gå inn på deres arena og satse flermedialt. Å kapre markedsandeler i publikums- og annonsemarkedet var en viktig motivasjonsfaktor. Mange av avisenes årsberetninger omtaler TV-reklame som en trussel etter at den kommersielle norske kanalen TV2 ble lansert i 1992 - og det gjaldt særlig i kampen om de lønnsomme kjedekundene og merkevareannonsørene. Dette forklarer at flere avishus kjøpte seg inn i lokale radio- og TV-stasjoner på 1990- og første halvdel av 2000-tallet. Flere av de større avisene i denne undersøkelsen har i perioder hatt lokale radioog/eller TV-stasjoner knyttet til seg. Resultatet ble at vi fikk flermediale bedrifter også lokalt.

$\AA ̊$ investere i ny teknologi og produkter i voksende markeder regnes som en fremtidsrettet konsern- og porteføljestrategi. «Det kan konstaterast at aksjemarknaden har hatt stor tru på multimedial ekspansjon, noko som til tider har synt seg svoert tydeleg $i$ utviklinga av aksjekursen til ulike mediefirma», konkluderte Roppen (2004:30). Det er forenlig med en standard analyse av en produktportefølje (BCG-analysen, se fig. 3, Jobber og Fahy, 2006:149-150). The Boston Consulting Groups (BCG) matrise kan brukes av bedrifter uansett bransje til å avgjøre hvilke produkter de bør satse på (fig. 3).

Det optimale her er at gamle lønnsomme produkter («melkekyr») brukes til å gjøre nye usikre produkter («spørsmålstegn») om til nye lønnsomme produkter («stjerner»). Overført til mediebransjen kan det innebære å drive papiravisa så lenge den gir inntekter, men uten å investere mer enn nødvendig i den. Man investerer i andre medieplattformer som ennå ikke har nådd metningsfasen i markedet. Slik kan avishuset ta skrittet inn i fremtiden ved å skape seg om til en flermedial bedrift. Avisenes 
Figur 3. BCG Lønnsomhetsmatrise (Jobber og Fahy, 2006)

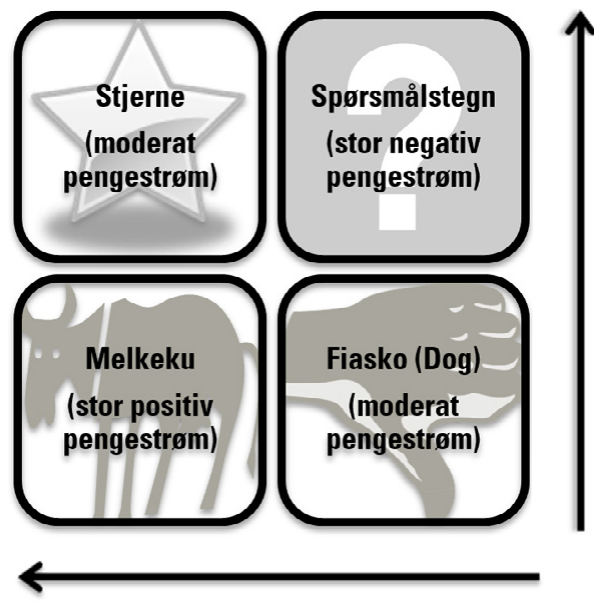

Vekst

Lønnsomhet

vurderinger av konkurranseforholdene, kjøp av TV-aksjer og - for mange - påfølgende konkurs, er også en utvikling dette materialet gir god anledning til å følge. TV-eventyret viste seg å bli mindre lønnsomt enn forventet. Hovedsakelig på grunn av annonsetørke etter finanskrisen, ble 13 av 24 norske lokale TV-stasjoner nedlagt i 2008 og 2009. Flertallet var eid av regionale avishus (Økonomien i norske medier 2005-2009 2010: 20-21). Nå betraktes isteden nyheter på nett og mobil som vektsproduktene. Men det er fortsatt papiravisa som gir størst inntekter per kunde, med klar margin (Høst 2013: 45-48). Dette er nok også med på å forklare at nye papiraviser startes.

Når det gjelder kundene, er deres forhandlingskraft styrket gjennom det store tilfanget av substitutter. Papiravisa er ikke lenger et selvsagt produkt man henvender seg til når man vil kjøpe annonseplass eller når man vil vite siste nytt. Substituttene bidrar til å endre kundenes krav, og senker betalingsviljen. Det går helt tydelig fram av materialet i undersøkelsen at avisene vet at konkurransen ikke lenger bare står om hvilken avis publikum vil ha - men om de vil ha aviser i det hele tatt. Samtidig skaper kjededannelser i varehandelen en ny type annonsekunder som er lite interessert i å annonsere i små lokalaviser med få lesere. Det betraktes som et alvorlig problem: «Innen varehandelen fortsetter utviklingen av kjeder, beslutning om å kjøpe annonse- 
plass også i lokalavisene tas $i$ stadig større grad på sentralt hold» (Fremover, Årsberetning for 1994). Denne utfordringen meldte seg med tyngde på 1990-tallet, og er fortsatt merkbar for uavhengige småbedrifter i bransjen. Løsningen blir at også avisene samarbeider i kjeder, eller ved å opprette annonsesamkjøringer der annonsøren bestiller annonse én gang, og få en rad annonser i en rekke aviser.

La oss nå se litt nærmere på faktoren potensielle nye aktører $i$ bransjen. Antakelser om at papiravismarkedet var mettet, har hittil vist seg å slå feil. I årene som var omfattet av denne undersøkelsen, og også etterpå, er det etablert nye papiraviser, og her er de superlokale småavisene en interessant gruppe. At de har opplagsvekst i startfasen, er en nødvendig del av etableringsprosessen. Derfor er det mest interessant å se på dem som har fremgang over mange år, som en hel del av dem har (Høst 2012, 2013). De har altså funnet en dyrkbar nisje. Et av Porters råd går ut på at man bør posisjonere bedriften der hvor konkurransekreftene virker svakest. For en lokalavis kan en slik løsning være nettopp det å finne en egen lokalgeografisk nisje. Her trenger de ikke å slåss mot mer ressurssterke riksmedier for å være nyhetsledende - i et begrenset nedslagsfelt kan de være nærmest enerådende.

Digitaliseringen har også banet veien for nye papiraviser. De nystartede lokalavisene har hatt et klart fortrinn ved å kunne gå rett inn i dagens digitale hverdag. Små aktører i bransjen opplever at den teknologiske terskelen for nyetablering er senket relativt sett, noe som også gjenspeiles i mitt datamateriale. Når det har blitt vanlig å kjøpe trykkeritjenester istedenfor å ha eget trykkeri, er en PC med den rette programvaren og en god trykkeriavtale i prinsippet alt som trengs for å starte en liten papiravis. Dermed er også den økonomiske inngangsterskelen senket. Dette ser ut til å ha vært en viktig forutsetning for grasrotprosessen. Her legges det imidlertid vekt på digitalisering i produksjon framfor i forbindelse med publisering. Selv om det også etableres nye lokale nettaviser i Norge, er nettet foreløpig lavt prioritert for mange ultralokale aviser i denne undersøkelsen. Det kan henge sammen med hvor inntektsmulighetene finnes - og med vanene til leserne deres. En potensielt viktig kundegruppe er voksne folk som er vant til å lese papiravis, og som kanskje savner at avisa i den større nabobyen ikke lenger dekker deres hjemsted. Når 
det gjelder fremtiden, ser småskalaaviser likevel ofte for seg et utvidet tilbud på nett, siden yngre lesere foretrekker nett framfor papir.

\section{Konklusjon}

Det er tydelig at lokalpressen her i utkanten av Europa har møtt de samme utfordringene som nær sagt hele verdenspressen - med digitalisering, økt konkurranse og fallende inntekter. I tillegg har de nordnorske avisene sin gamle utfordring med små lokalmarkeder og store distribusjonsbehov. Ved å følge et utsnitt av bransjen over tid på denne måten, går det an å finne noen svar på hvordan problemene ble forsøkt løst.

Hovedinntrykket av utviklingen blant betalte lokalaviser i Nord-Norge de siste tjue årene, er at utviklingen her ikke kan beskrives som én, men som to motsatte prosesser. Den ene kan kalles konsernifiseringsprosessen der mediekonsern innlemmer stadig flere lokale aviser, og får økende makt. Konsentrasjon er et sentralt stikkord for å beskrive denne utviklingslinjen: Her ser vi konsentrasjon om kjerneområder, konsentrasjon om kjerneprodukter, og eierkonsentrasjon. I møte med utfordringer fra leverandørsiden har konserntilknyttede aviser klare stordriftsfordeler. De har hatt større ressurser til å møte utfordringen fra digitale substitutter gjennom flermedial satsing. Overfor kjedeannonsører har konsernaviser også en fordel, alternativet er samarbeid i annonsesamkjøringer. Slik sett har disse avisbedriftene håndtert en del av utfordringene som beskrives i Porters modell i kraft av $a$ voere store. For at uavhengige aviser skal klare seg i lengden, trenger de enten pressestøtte eller en solid basis i lokale annonsøreroftest begge deler, avhengig av forholdene i det lokale omlandet.

Den andre prosessen kan kalles grasrotprosessen, der nye små uavhengige aviser startes på lokalt initiativ. Mange av nykommerne i denne gruppen har etablert seg i overensstemmelse med et annet av Porters råd, som går ut på at man bør posisjonere bedriften der hvor konkurransekreftene virker svakest. For en lokalavis kan en slik løsning være det å finne en egen lokalgeografisk nisje hvor det trengs, relativt sett, mindre ressurser for å etablere seg og for å rekke over hele dekningsområdet. Den tek- 
nologiske utviklingen har også senket inngangsterskelen for nye småaktører i bransjen. Her finnes fordeler ved å voere liten .

Den overordnede tendensen er da at mens etablerte aviser ble samlet i konsern, spirte nye små opp. Hovedinntrykket er at mediemarkedet er todelt, der de store gamle mediebedriftene har hatt mange tunge utfordringer, og vært igjennom kostbare omstillinger, mens mange av de nye små hittil har ridd på en medgangsbølge. De kunne også skreddersy sin forretningsmodell, sitt nedslagsfelt og sin profil til dagens rammebetingelser. Her ser det ut til at markedsforhold, teknologiske muligheter, politiske forhold i form av pressestøtten, naturgitte/geografiske forhold og sosiale forhold sammen har fremmet det superlokale mediemarkedet. Det ser også ut til å være en hel del idealisme inne i bildet: ønsket om å styrke og ta vare på sitt eget lokalsamfunn. Både en del lokale initiativ og det sentrale politiske målet om å bidra til mediemangfold gjennom offentlig støtte, kan betraktes som reaksjoner mot sentraliseringstiltak i regi av større medieaktører. Dermed er det også klart at de to motsatte prosessene i det nordnorske medielandskapet må ses i sammenheng. Det vil være svært interessant å sammenlikne med liknende tendenser andre steder, for eksempel i andre strøk med et desentralisert bosetningsmønster, eller i det hele tatt steder der nye småskala mediebedrifter blir etablert som alternativ til mainstream konsernmedier.

\section{REFERANSER}

Andenæs, Ivar (2003). Krig og fred $i$ Bodø: da to aviser ble til én: årsaker og konsekvenser: innholdsanalyse og intervjuer med avisens ansatte, kilder og lesere. Fredrikstad: Institutt for journalistikk. Rapport nr. $3 / 2003$.

Andøyposten, årsberetning 1994

Bakke, Hallvard (2000). NOU 2000:15 Pressepolitikk ved et tusenårsskifte: Dagspresseutvalgets innstilling avgitt til Kulturdepartementet. Oslo: Statens forvaltningstjeneste.

Barlindhaug, Johan Petter (2004). NOU 2004: 19 Livskraftige distrikter og regioner: rammer for en helhetlig og geografisk tilpasset politikk. Distriktskommisjonens utredning avgitt til Kommunal- og regionaldepartementet. Oslo: Statens forvaltningstjeneste. 
Bodøgaard, Jan Oscar (2012). «Konkurranse, krig og sammenslåing (1990-2002)», pp. 198-221. In: Wilhelm Karlsen og Svein Lundestad (red.), Start pressen! Avisene i Bodø gjennom150 år. Trondheim: Tapir Akademisk.

Finmark Dagblad, årsberetning 1990.

Forskrift om medieregioner, 2005-07-01 nr. 754. http://www.lovdata. no/for/sf/ku/xu-20050701-0754.html. Besøkt 23.04.2013.

Fremover, årsberetning 1994.

Harstad Tidende, årsberetning 1995, 1998, 1999.

Helgeland Arbeiderblad, årsberetning 1990.

Holand, Astrid Marie (2012). «Ny avis i en ny mediehverdag (20022012)», pp. 222-245. In: Wilhelm Karlsen og Svein Lundestad (red.), Start pressen! Avisene $i$ Bodø gjennom150 år. Trondheim: Tapir Akademisk.

Hansen, Tarjei Eck, Astrid Marie Holand og Lisbeth Morlandstø (2014, under utgivelse). «Innovasjon og alliansebygging - historien om en ny lokalavis». In: Lisbeth Morlandstø og Arne H. Krumsvik (red), Innovasjon og verdiskaping i lokale medier. Oslo: Cappelen Damm Akademisk.

Høst, Sigurd (2011). Avisåret 2010. Høgskulen i Volda og Møreforsking. Rapport nr. 18/2011.

Høst, Sigurd (2012). Avisåret 2011. Høgskulen i Volda og Møreforsking. Rapport nr. 29/2012.

Høst, Sigurd (2013). Avisåret 2012. Høgskulen i Volda og Møreforsking. Rapport nr. 37/2013.

Jobber, David og John Fahy (2006). Foundations of marketing. London: McGraw-Hill.

Kartverket 2013: Arealstatistikk for Norge (2013). http://www.statkart. no/Documents/Fakta\%20om\%20Norge/Arealstatistikk_fylker_2013. pdf Besøkt 23.04.2013.

Krumsvik Arne H. (2012). «Why old media will be funding journalism in the future», Journalism Studies, 13:5-6, pp. 729-741. Routledge online DOI:10.1080/1461670X.2012.664331.

Larsen, Bjørn (1992). NOU 1992:14 Mål og midler $i$ pressepolitikken: utredning avgitt til Kulturdepartementet, Oslo: Statens forvaltningstjeneste.

«Medieåret 2008-2009. Medieutvikling i Norge: Fakta og trender» (2010). Medienorge, Institutt for informasjons- og medievitenskap, Universitetet i Bergen. 
Meyer, Philip (2004). The Vanishing Newspaper: Saving Journalism in the Information Age. Columbia: University of Missouri Press.

Nordicom statistikk (2013). http://www.nordicom.gu.se/?portal=mt\&main=showStatTranslate.php\&me $=1 \&$ media=Newspapers $\&$ type $=-$ media\&translation=Dagspress: «Number of newspapers 2010» og «Paid-for newspapers: Circulation per thousand inhabitants 20022010». Besøkt 17.08.2013.

Okkenhaug, Håkon (2011). Flere lesere - mindre opplag. En analyse av opplagsfallet i norske dagsaviser 2002-2010. MBA Næringslivsjournalistikk, Bodø: Universitetet i Nordland.

Porter, Michael E. (2008). «The Five Competitive Forces That Shape Strategy", Harvard Business Review, January 2008, pp. 86-104.

Roppen, Johann (2004). Medieindustrien. Innføring $i$ medieøkonomi. Oslo: Samlaget.

Roppen, Johann (2012). Mediestruktur og mediestøtte i Norden. Paper presentert ved Norsk medieforskerlags medieforskerkonferanse. Kristiansand, Norway.

Skarstein, Vigdis Moe (1995). NOU 1995:3 Mangfold i media: om eierkonsentrasjon i massemedia: utredning fra Eierskapsutvalget avgitt til Kulturdepartementet. Oslo: Statens forvaltningstjeneste.

Skogerbø, Eli (2012): Medieeierskap - medievitenskapelig analyse. Delutredning til Prop. 142 L (2012-2013) Proposisjon til Stortinget (forslag til lovvedtak) Endringer i medieeierskapsloven.

Slettholm, Yngve (2010). NOU 2010:14 Lett å komme til orde, vanskelig å bli hørt-en moderne mediestøtte. Utredning fra et utvalg oppnevnt av Kulturdepartementet. Oslo: Departementenes servicesenter.

Statistisk Sentralbyrå (2012). «Innenlandske flyttinger, etter kommunens sentralitet. Hele landet. 1996-2011», SSB 2012. http://www.ssb. no/emner/02/02/20/flytting/tab-2012-05-11-15.html.

Besøkt 23.04.2013.

Statistisk Sentralbyrå (2013). «Folkemengde 1. januar 2012, endelige tall». http:// www.ssb.no/statistikkbanken. Besøkt 23.04.2013.

Sør-Varanger Avis, årsberetning 1998.

USC Annenberg School Center for the Digital Future (2012): Special Report: America at the Digital Turning Point. University of Southern California. CDF_DigitalReport. Besøkt 27.10.2013.

Østhavet, årsberetning 1997.

Aalbu, Hallgeir (2004). NOU 2004: 2. Effekter og effektivitet. Effekter av statlig innsats for regional utvikling og distriktspolitiske mål. Utred- 
ning fra Effektutvalget, avgitt til Kommunal- og regionaldepartementet. Oslo: Statens forvaltningstjeneste.

Aarsæther, Nils og Torill Nyseth (2011). «Liv laga? Stedsutvikling og stedsstrategier i nord» pp. 55-66. In: Svein Jentoft, Jens-Ivar Nergård og Kjell Arne Røvik (red.), Hvor går Nord-Norge? Tidsbilder fra en landsdel i forandring. Bd. I. Stamsund: Orkana Akademisk.

1 Kriteriet for å bli med i undersøkelsen, er at de ga ut en papiravis med minst én utgave i uka, at de var i drift i minst fire år og at de tok betalt for papiravisa. Variasjonen i opplag og nedslagsfelt er stor. Opplagstallene varierer fra 1000 til 23000 (pr. 2012).

2 Kilder for datamaterialet er Brønnøysundregistrene, Medietilsynet, Mediebedriftenes Landsforening (MBL) og Landslaget for lokalaviser (LLA), samt de årlige rapportene Avisåret fra Sigurd Høst, Høgskulen i Volda og Medieåret fra Medienorge, Universitetet i Bergen.

3 Følgende nøkkelopplysninger ble registrert for hvert år fra 1990 til 2010: 1) eierskap, 2) konserntilknytning (ja/nei), 3) godkjent nettoopplag for papirutgaven, 4) antall ansatte, 5) årsresultat (overskudd/underskudd), 6) driftsmargin (driftsresultat som andel av driftsinntekt, før skatt) og 7) pressestøtte.

4 Fire av disse er så nye at de ikke kom med i undersøkelsens hovedmateriale.

ASTRID MARIE HOLAND er stipendiat i historie ved Universitetet i Tromsø (UiT), og tilknyttet Forskningsgruppe for journalistikk ved Universitetet i Nordland (UiN). Hun har mastergrad i historie fra UiN og har arbeidet 15 år som journalist $i$ Norsk Rikskringkasting (NRK). Materialet i artikkelen er samlet i forbindelse med to forskningsprosjekter i regi av UiN der Holand deltar: Start pressen! Avisene i Bodø gjennom 150 år og Lokaljournalistikkens vilkår og muligheter i et nordnorsk mediemarked.

astrid.m.holand@uit.no 